\title{
Article \\ The Impact of Environmental Sustainability Disclosure on Stock Return of Saudi Listed Firms: The Moderating Role of Financial Constraints
}

\author{
Abdulaziz Mohammed Alsahlawi, Kaouther Chebbi (1) and Mohammed Abdullah Ammer* \\ Department of Finance, School of Business, King Faisal University, Al-Ahsa 31982, Saudi Arabia; \\ amalsahlawi@kfu.edu.sa (A.M.A.); Kchebbi@kfu.edu.sa (K.C.) \\ * Correspondence: mammer@kfu.edu.sa
}

Citation: Alsahlawi, Abdulaziz Mohammed, Kaouther Chebbi, and Mohammed Abdullah Ammer. 2021. The Impact of Environmental Sustainability Disclosure on Stock Return of Saudi Listed Firms: The Moderating Role of Financial Constraints. International Journal of Financial Studies 9: 4. https://doi.org/10.3390/ ijfs9010004

Received: 15 November 2020 Accepted: 29 December 2020 Published: 5 January 2021

Publisher's Note: MDPI stays neutral with regard to jurisdictional clai$\mathrm{ms}$ in published maps and institutional affiliations.

Copyright: (C) 2021 by the authors. Licensee MDPI, Basel, Switzerland. This article is an open access article distributed under the terms and conditions of the Creative Commons Attribution (CC BY) license (https:// creativecommons.org/licenses/by/ $4.0 /)$.

\begin{abstract}
Environmental sustainability represents nowadays a significant factor for business sector. Firms carry out many initiatives to develop environmental practices. Investors increasingly consider environmental discloser by firms and integrate this disclosure into the investment decision-making process. Using a database of Saudi listed firms, this study adds to the literature by examining the relationship between the environmental sustainability disclosure and stock return and whether this relationship is moderated by the financial constraints. We find that the environmental sustainability disclosure has significant and negative impact on stock return, indicating that investors do not consider environmental disclosure when valuing the stocks. Furthermore, our results propose that the negative impact of environmental disclosure on stock return is more evident in firms with financial constraints. This study provides managerial implications for regulatory authorities, firms and investors. The environmental practices can be value relevant. However, these practices need to be efficiently integrated into stock valuation.
\end{abstract}

Keywords: stock return; environmental sustainability disclosure; financial constraints; Saudi Arabia

JEL Classification: G11; G32; Q56

\section{Introduction}

Contemporary business is regularly changing owing to the new risks and challenges associated to ethical, social and environmental concerns (Grubor et al. 2020). The stakeholders' awareness of social responsibility of firms have been increased. Firms, governments, regulatory authorities, investors and consumers all over the world pay more attention for environmental sustainability issues (Gregory-Smith et al. 2017). The societies around the world are greatly concerned in recognizing that firms are really committed to environmental protection from issues like emissions, climate change, contamination, and other environmental influences arising from the operations of firms. Therefore, firms are increasingly more interested for legitimizing themselves by disclosing their environmental activities and practices (Llena et al. 2007). By disclosing environmental activities and its impacts to stakeholders, firms will construct a positive image (Bhattacharyya and Cummings 2015).

Recently, as investors and policymakers are more interested in socially responsible investments, the significance of environmental, social, and corporate governance (ESG) elements in taking investment decisions has improved (La Torre et al. 2020). Along the same line, Indriastuti and Najihah (2020) point out that the outstanding performance of firms regarding environmental practices become the key concern for the investors.

Disclosing environmental sustainability practices by firms will result in reducing information asymmetry amongst investors. Likewise, reporting of environmental information lessens the uncertainty associated with capital providers indicating that capital might be obtained at lower cost (Cowton and Thompson 2000; Plumlee et al. 2010). Healy et al. (1999) indicate 
that the liquidity of stocks will be improved as well as the undervaluation of stocks will be corrected by expanded disclosure of firms. Porter (1991) clarifies that cost of implementing environmental sustainability will be compensated by developing the productivity of firm. Brammer et al. (2006) propose that improved corporate social performance will result in enhanced stock returns. They argue that the return will be increased by cost declines, efficiency enhancements, and firm reputation improvement which encourage financial analysts to recommend the firm stocks and investors to hold them. To this end, Jizi et al. (2016) signify that management of firms send indications to their stakeholders to distinguish their firms and get the benefit from higher price of stocks.

La La Torre et al. (2020) claim that the firms need to encounter greater cost and deal with several environmental-driven risk when responding to the increasing demand for sustainable products. For example, the share price of Volkswagen firm declined by $18 \%$ in 2014 as a result of the firm emission scandal indicating how environmental practices could lead to reputational risk which in turn will affect the financial performance of the firm (La Torre et al. 2020). Thus, compliance with environmental standards may improve the image of the firm and reduce the negative effect of undesirable events on its share price (Godfrey et al. 2009).

The markets assess the environmental approach of the firms when selecting investments. Bénabou and Tirole (2010) argue that when the firms avoid taking the short-sighted decisions concerning ESG arrangements, they will be able to enhance their market position. Consequently, by investigating whether the investors care about disclosing of environmental sustainability practices, the first objective of this study is to examine the impact of disclosing such environmental information on the Saudi stock return.

In corporate finance, a vital concern is the influence of financial constraints on performance and behavior of firms ( $\mathrm{Li}$ and Luo 2019). Kurt (2018) indicates that financial constraints have great influence on the accounting information quality. Further, while Campello et al. (2010) report strong relationship between financial constraints and investment behavior of firms, Chen and Wang (2012) document that the decisions of stock repurchase are impacted by the financial constraints.

The frictions that face the firms and prevent them from financing the preferred investments are considered financial constraints (Lamont et al. 2001). In line with the developing task of corporate social responsibility (CSR), firms increasingly take into account removing the constraints and undertake more investments in CSR (Pava and Krausz 1996). With the enhanced practices of CSR, a lower return can be accepted by the investors.

Almeida et al. (2004) display that the spending on investments has more sensitivity to internal cash flow for the firms associated with financial constraints compared to an unconstrained firm. He and Ren (2018) indicate that these financially constrained firms require more cash to enable them to encounter the corporate default. Thus, investing in environmental initiatives could be less for firms with financial constraints that possibly will lead to lowering the return of these firms' stocks as the investors will avoid such stocks. Lamont et al. (2001) indicate that firms with financial constraints provide reduced returns than unconstrained firms. On the contrary, as investors request greater returns for stocks related with greater risk, Livdan et al. (2009) point out that firms with financial constraints provide more return since they include more risk than unconstrained firms. Based on Campello and Chen (2010), the macroeconomic circumstances are the reasons that lead to mixed associations between financial constraints and stock returns.

Götz (2018) indicates that the role of financial constraints in environmental responsibility of firms is still an open question. Fowlie et al. (2015) and Greenstone et al. (2012) point out that investments in order to decrease contamination and protect energy are relatively huge. Further, Walker (2011) claims that costs attributable to fulfilling the environmental regulation can be large. Consequently, decreasing financial constraints could enable firms to increase their investment in environmental activities to reduce the pollution and negative impacts on all stakeholders, which may have a positive impact on the firm's stock return. 
Thus, Zhang et al. (2020) argue that for CSR fulfillment, firms have the incentives to lessen financial constraints.

The CSR can also lessen the financing constraints of firms. CSR can decrease information asymmetry between the firm internal and external stakeholders, which will result in decreasing firm's agency cost (Zhang et al. 2020). Further, disclosing CSR information enhance the firm's transparency (Lambert et al. 2007), increases the confidence of stakeholders (Andreea and Valeriu 2015), and alleviate the firm financial constraints (Zhang et al. 2020), which may result in enhancing the stock return of firms.

Consequently, a better understanding of the interaction influence of financial constraints on the relationship of environmental reporting-stock return is significant for the stakeholders like investors or the decision-makers in firms. Thus, the second objective of our study is to explore whether the association between environmental disclosure and stock return is impacted by the financial constraints.

Utilizing a sample of Saudi listed firms, we point out that the association between environmental sustainability disclosure and stock return is strong and negative. This results show that environmental sustainability is likely to be value relevant, but it is not well integrated into stock return. That is, the environmental disclosure appears not to be possible instrument to enhance shareholders value. Therefore, firms that disclose content of environmental sustainability are not able to decrease the amount of information asymmetry in order to improve their stock's return. Moreover, Alotaibi and Hussainey (2016) reveal that in Saudi Arabia, there is a lack of consideration from the policy makers concerning CSR disclosure as they think it is not important for investors. Further, we find that this negative relationship between environmental sustainability disclosure and stock return is more pronounced for firms with high financial constraints which signifies that firms that cannot invest in environmental sustainability practices will face lower stock return.

This study aims to contribute and add to the current literature in a number of ways. First, we extend the existing literature on environmental sustainability disclosure, stock return and financial constraints. The financial consequences of environmental sustainability disclosure on stock return behavior have not been sufficiently addressed in previous literature. Moreover, the results of a number of earlier studies (e.g., Brammer et al. 2006; Halbritter and Dorfleitner 2015; Tasnia et al. 2020; Indriastuti and Najihah 2020) are inconclusive and equivocal as well as did not provide clear conclusion whether the stock return is valued or devalued by environmental disclosure. Thus, our study fills these gaps in previous literature by providing new evidence concerning whether environmental sustainability disclosure is valued or overlooked in financial markets.

Second, previous evidences examined the direct relationship between environmental practices and financial constraints (e.g., Yao et al. 2019), ESG and financial constraints (e.g., Hong et al. 2012) and CSR and capital constraints (e.g., Cheng et al. 2014). However, our study differs from previous once as it is the first to investigate the moderating impact of financial constraints on the relationship between environmental disclosure and stock return. In fact, this moderation association is still equivocal, which establishes another motivation for conducting this study. Accordingly, our study adds to literature by filling this gap.

Third, earlier studies examine the environmental disclosures-stock return relationship in developed countries where investors have better awareness of the significance of environmental protection and disclosure. However, the literature related to this issue is very limited in developing and emerging markets. Further, environmental sustainability disclosure is not yet a well-established concept in the developing countries as well as the invest in environmental sustainability and reported data still limited in these countries. Thus, this study fills this gap by examining this issue in Saudi Arabia as a developing country. To the best of our knowledge, this is the first study to examine environmental disclosures-stock return relationship in Saudi Arabia.

Saudi Arabia is a unique context for conducting this study for some reasons. First, in Saudi Arabia, the improvement of economic and social is motivated primarily by Islamic 
law (Shari'ah principles). Dusuki and Abdullah (2007) indicate that the individuals and businesses will act toward CSR based on Islamic teachings which provide several spiritual instructions regarding the ethics and principles of business conduct. That is, the practices of management of Saudi firms toward environmental sustainability will be different from other countries that are not employing Shari'ah principles. In their study, Ali and Al-Aali (2012) report that CSR for Saudi managers represents a commitment to them based on the Islamic perception.

Second, Saudi Arabia is one of the Gulf Cooperation Council (GCC) members. Eljayash et al. (2012) indicate that the area of GCC was related with insignificant levels of environmental disclosure through listed firms. However, latest studies report growing in environmental disclosure across the area (e.g., Gerged et al. 2018). In Saudi Arabia, firms increased the consideration to the CSR accomplishments in their annual reports (Alotaibi and Hussainey 2016). Additionally, Saudi Arabia is considered to be among the biggest producers of oil in the world. Even though environmental disclosure in Saudi Arabia is still voluntary, official efforts to enhance environmental responsibility have improved. The vision 2030 of Saudi Arabia that launched in 2016 has an important objectives concerning environmental development. The country works on supporting sustainable development, improve the environments of business in addition to attracting more foreign investments (Alhazmi 2017). The government of Saudi Arabia motivate the private sector to increase its involvement to the social and economic development by leading CSR initiatives and forums as well as increasing awareness about the significance of CSR importance (Alhazmi 2017). Thus, providing evidence on environmental disclosure-stock return relationship in the context of Saudi Arabia is expected to enrich the literature.

Finally, the results of this study may provide some significant practical implications. The results might be invaluable to firms' management for reconsidering their disclosure strategy in a way that enhance the stock return. The results also provide motivation to regulatory authorities to increase the awareness of investors and other stakeholders about the significant value of considering the environmental sustainability disclosure and initiatives. Further, the study provides guidance for individual and institutional investors on the importance of evaluating environmental sustainability disclosure for firms to identify the heavily polluting firms that will be related with higher risk.

The remainder of this study is structured as follows: the subsequent section demonstrates a review for literature besides developing the study's hypotheses. In the third section, we present the research methodology including the construction of sample, research models and measurement of variables. In the fourth section, we present and discuss the results. The fifth section draws conclusions and presents the implications.

\section{Literature Review and Hypotheses Development}

Market environment nowadays is more socially conscious, which enabled sustainability trends to change the way firms operate their activities (Nizam et al. 2019). That is, sustainability becomes new concept for firms where they not only focus on the financial sustainability but also they need to consider the social and environmental influences on all stakeholders (Nizam et al. 2019).

\subsection{Direct Relationship between Environmental Sustainability Reporting and Stock Return}

Recently, the literature on ESG factors have concentrated on a more identified perception like the association between ESG and stock price (La Torre et al. 2020). Indriastuti and Najihah (2020) report that the stock return is positively related with the environmental performance indicating that investors react more positively to these firms with higher environmental disclosure. In the same vein, Eccles et al. (2014) find that firms with better ESG have annual abnormal returns of up to $4.8 \%$.

Limkriangkrai et al. (2017) investigate the impact of environmental ranking on stock return for a sample of Australian firms. They report a high return for portfolios with high environmental ratings. It is pointed out by Giese and Nagy (2018) that firms with low ESG 
scores are encountered by more sensitive reaction from stock markets. In their studies, Klassen and McLaughlin (1996) and Jacobs et al. (2010) indicate that the reaction of market was positive for environmental awards and performance. They add that the earnings gain and cost decreasing enable the firms to enhance their financial performance. Further, Ender and Brinckmann (2019) report that when the firms announce positive environmental news, the abnormal returns will be impacted strongly and positively.

It is proposed by Hussainey and Salama (2010) that share price of firms with greater reputation and ranking in terms of environment will receive higher expectation of earnings than other firms with lower environmental reputation and ranking. Miralles-Quiros et al. (2017) claim that good environmental management and CSR may enhance the firm value as a result for the positive response of investors. Further, Sahut and Pasquini-Descomps (2015) examine the impact of ESG news on the stock returns in many countries (Switzerland, US, UK) through 2007-2011. They document small but substantial influence on the performance of the stock. Moreover, Karagiorgos (2010) and Stekelenburg et al. (2015) argue that the firms associated with high CRS practices will be rewarded by the market via substantial positive growing in their stock returns.

Stakeholder theory indicates that the main aim of a business is to enhance the interests of stakeholder (Friedman 1970). Firms with great environmental sustainability disclosure constructs the opinion of stakeholders that these firms have good reputation and image. Stakeholders have the right to get information about environmental activities to help their decision making. Indriastuti and Najihah (2020) show that firms seek to enhance their image to get the legitimacy and acceptance of stakeholders resulting in increasing the investing in firm, and thus increasing the stock return. Therefore, we assume higher stock return for firms with improved environmental performance and initiatives.

Fatemi et al. (2018) used that data of publicly listed U.S. firms to point out the moderation role of ESG-related disclosure on the relationship between the practices of firm's ESG and its valuation. They reveal that the disclosure of ESG practices support the firm to lessen the negative influences of issues concerning ESG performance on its valuation. Moreover, they report that disclosure is negatively associated with the value of firms with ESG strengths. They also document that investors distinguish among the environmental, social, and governance scores pertaining to their informational content.

The reaction of stock market to ESG disclosure has been examined by Capelle-Blancard and Petit (2019). Specifically, they employed 33,000 ESG news for one hundred worldwide firms. Their results reveal that the market value of firms that encounter undesirable events decreased by $0.1 \%$. On the other side, on average, firms did not gain anything from positive ESG news.

The disclosing of environmental activities is explained also by the signalling theory. The theory proposes that for firms to differentiate themselves, they send signals about their positive outcomes. Thus, firm employs the CSR disclosure as a signal to their investors that it involves in CSR initiatives. This will be resulting in supporting the positive image of the firms in the market (Sun et al. 2010) and their stocks value will be increased as the demand on these stocks and valuation will be adjusted following CSR disclosures. In fact, the image and reputation risks related with ESG can impact the stock price of firms in the market (Sahut and Pasquini-Descomps 2015). Hence, reducing the risk of ESG should not be neglected. The signaling power that CSR deliver is identified by its operative communication to huge number of stakeholders (Godfrey et al. 2009). If investors anticipate that firms can utilize the good environmental performance to create value, they will by acting positively and enhance the stock price of such firms.

Based on the above discussion, we developed our first hypothesis that environmental sustainability disclosure will boost the investors' expectations concerning the positive value and financial performance of firms that will be resulting in increasing the stock return. Therefore, this study hypothesizes that

Hypothesis 1 (H1). Environmental disclosures enhances stock return. 


\subsection{Moderating Effect of Financial Constraints in Environmental Sustainability Reporting-Stock Return Relationship}

Financial constraints represent the amount of fund that is available for firm for financing its selected investments (He and Ren 2018). The financial friction resulted due to information asymmetry between firms and investors is a kind of financial constraints (Tirole 2006). Financially constrained firms are related with greater cost of capital and delay of its projects as their possibilities to fail is high, thus intensifying the risk of stock price crash (He and Ren 2018). Investors need to evaluate the risk of a firm's financial constraints by measuring its available internal fund besides its capability to increase external funding (Dechow et al. 1996). Financial constraints could restrain the firms from having the sufficient funding. Previous evidences (e.g., Lamont et al. 2001; Livdan et al. 2009) reveal that the stock return of firms with financial constraints are not greater than unconstrained firms. That is, the investors are not able to assess the valuation effect of financial constraints. Thus, financial constraints are an essential element for financing and investment decisions of firms (Xiao and Wang 2020).

Hong et al. (2012) indicate that firms with good performance in ESG will face lower financial constraints. Likewise, Cheng et al. (2014) point out that firms with better performance of CSR are related with less capital constraints. The firms with more contaminations issues are more motivated to disclose extensive environmental information to decline the concerns of investors (Cho and Patten 2007).

Xiao and Wang (2020) find that the environmental labeling influences the financing channels of greatly polluting firms in China. They report that the issuance of future equities and the loans of banks are lower than other non-polluting firms. They add that greatly polluting firms are conducting more environmental activities which will lead to reducing their financial constraints.

Yao et al. (2019) show that disclosing of information may decrease the asymmetric information and probably reduce the financial constraints of firms. One of this information is the firms' environmental practices. Disclosing environmental information will enhance the firm transparency and will offer the stockholders important information concerning the ways that firms handle the environmental concerns. This environmental information will mitigate the ambiguity of investors regarding the interventions of regulatory as well as fines (Yao et al. 2019).

Consequently, we assume that the relationship between environmental sustainability disclosure and stock return is less pronounced when firms have financial constraints. Thus, our second hypothesis can be stated as follows:

Hypothesis 2 (H2). Financial constraints decrease the positive impact of environmental disclosures on stock return.

\section{Methods}

\subsection{Sample}

The sample of our study includes the firms listed on the Saudi stock exchange during the period of 2015-2019. Data relating to environmental sustainability disclosures, financial constraints, and firm-characteristics are collected from Bloomberg database. Bloomberg is one of the best systems for financial services that offers financial information for all market all over the world. It provides the data on ESG scores through collecting the data of CSR of firms and Bloomberg Sustainability Survey. Helfaya and Whittington (2019) recommended future studies to employ the environmental sustainability disclosure scores provided by Bloomberg.

Our initial sample involves 199 Saudi listed firms. However, we excluded 47 financial firms in addition to 28 real estate investment firms. This is in line with prior studies (e.g., Karamanou and Vafeas 2005; Ammer and Ahmad-Zaluki 2017). These firms have their specific requirements and regulation for disclosure as well as dissimilar accounting criteria. In addition, another 90 firms have been deleted due to their missing data whether on 
environmental disclosures, financial constraints, or firm-characteristics. The final sample consists of 34 firms and 170 firm-year observations.

\subsection{Research Models}

The dependent variable of our study is stock return. Thus we establish the first model to examine our first hypothesis that the associations between environmental disclosure and stock return is expected to be positive.

$$
\begin{array}{r}
R_{i, t}=\beta 0+\beta 1 \mathrm{ENV}_{i, t}+\beta 2 \mathrm{SIZE}_{i, t}+\beta 3 \operatorname{ROA}_{i, t}+\beta 4 \mathrm{ASSETGROWTH}_{i, t}+\beta 5 \mathrm{DEBT}_{\mathrm{i}, \mathrm{t}}+\beta 6 \mathrm{MTB}_{i, t}+\text { Industry }^{\text {dummies }}+\text { Year dummies }+\varepsilon
\end{array}
$$

Further, we perform the second model to examine the second hypothesis that the impact of environmental disclosure on stock return will be less enhanced in firms with financial constraints.

$$
\begin{aligned}
\mathrm{R}_{\mathrm{i}, \mathrm{t}}=\beta 0+\beta 1 \mathrm{ENV}_{\mathrm{i}, \mathrm{t}} \times \mathrm{FC}_{\mathrm{i}, \mathrm{t}}+ & \beta 2 \mathrm{FC}_{\mathrm{i}, \mathrm{t}}+\beta 3 \mathrm{ENV}_{\mathrm{i}, \mathrm{t}}+\beta 4 \mathrm{SIZE}_{\mathrm{i}, \mathrm{t}}+\beta 5 \mathrm{ROA}_{\mathrm{i}, \mathrm{t}}+\beta 6 \mathrm{ASSETGROWTH}_{\mathrm{i}, \mathrm{t}}+\beta \mathrm{DDEBT}_{\mathrm{i}, \mathrm{t}}+ \\
& \beta 8 \mathrm{MTB}_{\mathrm{i}, \mathrm{t}}+\text { Industry dummies }^{+} \text {Year dummies }+\varepsilon
\end{aligned}
$$

For the dependent variable of this study, R, stock return, is measured using monthly stock returns for our sample firms (Sahut and Pasquini-Descomps 2015; Indriastuti and Najihah 2020). Concerning the environmental disclosure, ENV, it is the score of environment that comes directly from Bloomberg database. This measurement is employed in many prior studies (e.g., Nollet et al. 2016; Manita et al. 2018). The Bloomberg scoring system shows that, firms with no disclosed information on environmental performance will be given zero and one hundred for firms with complete disclosed information on environmental performance. That is, the scoring system ranges between zero and one hundred. ENV $\times$ FC is the moderating variable. FC, financial constraints, is calculated as a dummy variable that equals one if the dividend payout ratio is higher than its median and zero otherwise (Fazzari et al. 1988).

Following previous studies (e.g., Jizi et al. 2016; Bolton and Kacperczyk 2020), five firm-characteristics variables used in our two models. The first one is firms size, SIZE, which is measured as the logarithm of market capitalization (Astakhov et al. 2019). The second variable is the profitability, ROA, that is calculated by return on assets ratio (Dbouk et al. 2018). The third used control variable is the growth of firm assets, ASSETGROWTH, measured as the growth rate of total assets (Cooper et al. 2008). We also control for firm debt, DEPT, calculated by total debt to total assets ratio (Rubino and Napoli 2020). Finally, we control for market to book ratio, MTB, measured by dividing market capitalization on the net book value (Pizzutilo et al. 2020). Based on the prior studies concerning ESG, it is indicated that ESG is industry specific (Mănescu 2011). Therefore, models (1) and (2) were estimated using industry dummies to enable controlling the confounding impacts. Finally, the expression year dummies denote the unobserved time-specific effects that are time-variant and common to all firms.

\section{Empirical Results}

\subsection{Descriptive Statistics}

In Table 1, we present the summary statistics for environmental disclosure within each industry sector and each year. While the highest score of ENV is for Technology industry with a mean of 40.49, the lowest score of ENV is for Industrials sector with a mean of 14.24. In Table 1 also, it can be noticed that ENV disclosure is almost comparable for firms during the years of study 2015-2019. Nevertheless, the ENV score to some extent show positive tendency and increases from one year to another till 2019. This suggests that Saudi firms are conscious of the environmental disclosure importance. 
Table 1. Descriptive statistics for environmental disclosure within each industry and years of the study.

\begin{tabular}{cccc}
\hline Years of Study & Mean of ENV & Industry & Mean of ENV \\
\hline \multirow{2}{*}{2015} & \multirow{2}{*}{14.79} & Communication Services & 20.79 \\
& \multirow{2}{*}{2016} & Utilities & 14.38 \\
\hline \multirow{2}{*}{2017} & \multirow{2}{*}{15.33} & Consumer Goods & 15.33 \\
& \multirow{2}{*}{15.40} & Health Care & 14.59 \\
\hline \multirow{2}{*}{2018} & \multirow{2}{*}{15.50} & Consumer Services & 22.97 \\
& \multirow{2}{*}{2019} & Materials & 18.57 \\
\hline \multirow{2}{*}{19.31} & Oil and Gas & 20.63 \\
& & Technology & 40.49 \\
\hline
\end{tabular}

Note: This table demonstrates the descriptive statistics for environmental disclosure (ENV) within each industry sector and each year. ENV is the score of environment that comes directly from Bloomberg database.

The descriptive statistics of our sample and all variables of study are demonstrated in Table 2. As displayed in this table, the mean of the stock return is 0.57 with a median of 0.80 and 1.89 for standard deviation, representing that there are quite differences in the stock returns levels among firms. During the period of 2015-2019, the average value of our key variable (ENV disclosure score) is 16.94 with standard deviation of 15.29. This reported average of ENV signifies that it is not efficient as the ranges of disclosure score is zero to one hundred. The Saudi firms need to invest more in environmental initiatives and practices. As we utilize the aggregate ESG scores, governance score (GOV) and social score (SOC), in our additional analysis, we include their descriptive statistics in Table 2. The average value of ESG is 17.08. Concerning the means of SOC and GOV scores its 17.62 and 40.36, respectively. These results show that GOV score (40.36) has great important in modelling the comprehensive ESG. Lastly, the average of financial constraints (FC) is 0.46 . Its standard deviation is 0.50 , showing that the FC is relatively different between firms.

Table 2. Descriptive statistics.

\begin{tabular}{|c|c|c|c|c|c|c|c|c|}
\hline Variables & $\mathbf{N}$ & Mean & STD & $\begin{array}{c}5 \text { th } \\
\text { Percentile }\end{array}$ & $\begin{array}{c}\text { 25th } \\
\text { Percentile }\end{array}$ & Median & $\begin{array}{c}\text { 75th } \\
\text { Percentile }\end{array}$ & $\begin{array}{c}\text { 95th } \\
\text { Percentile }\end{array}$ \\
\hline $\mathrm{R}$ & 170 & 0.57 & 1.89 & -2.80 & -0.71 & 0.80 & 2.02 & 2.81 \\
\hline ENV & 170 & 16.94 & 15.29 & 1.79 & 2.68 & 10.08 & 23.12 & 25.17 \\
\hline $\mathrm{FC}$ & 170 & 0.46 & 0.50 & 0 & 0 & 0 & 1 & 1 \\
\hline ESG & 170 & 17.08 & 11.97 & 1.79 & 10.33 & 14.91 & 19.42 & 42.98 \\
\hline $\mathrm{SOC}$ & 133 & 17.62 & 12.78 & 1.79 & 7.02 & 12.28 & 23.95 & 47.37 \\
\hline GOV & 144 & 40.36 & 13.39 & 6.67 & 39.29 & 44.64 & 44.64 & 55.57 \\
\hline SIZE & 170 & 10.64 & 10.24 & 2.27 & 2.75 & 3.11 & 23.12 & 25.17 \\
\hline $\mathrm{ROA}$ & 170 & 9.06 & 15.81 & -6.68 & 2.72 & 10.30 & 15.60 & 33.28 \\
\hline ASSETGROWTH & 170 & 0.04 & 0.14 & -0.08 & -0.01 & 0.03 & 0.10 & 0.200 \\
\hline DEBT & 170 & 22.78 & 20.27 & 0 & 4.51 & 15.86 & 39.78 & 58.55 \\
\hline МТВ & 170 & 1.78 & 1.80 & 0.09 & 0.59 & 1.30 & 2.33 & 5.66 \\
\hline
\end{tabular}

Note: This table demonstrates the descriptive statistics for the utilized variables in the study's models. The sample of this study includes 170 year-observation representing 34 Saudi listed firms during the period 2015-2019. R, stock return, is measured using monthly stock returns. ENV, environmental disclosure, is the score of environment that comes directly from Bloomberg database. FC, financial constraints, is calculated as a dummy variable that equals one if the dividend payout ratio is higher than its median and zero otherwise. ESG disclosure score, is environmental, social, and corporate governance total score. SOC, social score, it comes directly from Bloomberg database. GOV, governance score, it comes directly from Bloomberg database. SIZE, firms size, is measured as the logarithm of market capitalization. ROA, profitability, is calculated by return on assets ratio. ASSETGROWTH, growth of firm assets, measured as the growth rate of total assets. DEPT, debt, calculated by total debt to total assets ratio. MTB, market to book ratio, measured by dividing market capitalization on the net book value. 


\subsection{Correlation Analysis}

The Pearson correlation coefficients between the variables of the study is presented in Table 3. The correlation coefficients between the stock return and our explanatory variable ENV is negative, suggesting that ENV disclosure leads to lower stock return. Further, the stock return is strongly associated to SIZE and ROA with positive direction and DEBT with negative direction. Multicollinearity issue was determined using correlation matrix, which provided evidence to the non-existence of multicollinearity between the variables, as none of their correlations exceeded 0.80 . Furthermore, we calculate the variance inflation factors (VIF) and there is no multicollinearity issue as the tolerance value are higher than 0.10 , while VIF did not exceed 10 for the entire independent variables. Hence, the multicollinearity assumption was not breached.

Table 3. Correlations matrix.

\begin{tabular}{ccccccc}
\hline Variables & ENV & R & SIZE & ROA & ASSETGROWTH DEBT & MTB \\
\hline ENV & 1 & & & & & \\
R & $-0.392^{* * *}$ & 1 & & & & \\
SIZE & -0.071 & $0.213^{* *}$ & 1 & & & \\
ROA & $-0.345^{* * *}$ & $0.683^{* * *}$ & $0.179^{*}$ & 1 & & \\
ASSETGROWTH & 0.054 & -0.055 & -0.100 & -0.002 & 1 & 1 \\
DEBT & $0.220^{* *}$ & $-0.283^{* * *}$ & -0.110 & $-0.252^{* *}$ & -0.150 & 0.033 \\
MTB & 0.001 & 0.105 & $0.346^{* * *}$ & 0.089 & -0.047 & 1 \\
\hline
\end{tabular}

Note: This table demonstrates the Correlations matrix between the utilized variables in the study's models. The sample of this study includes 170 year-observation representing 34 Saudi listed firms during the period 2015-2019. ${ }^{* * *}, * *$, and ${ }^{*}$ demonstrate the levels of significance at: $0.01,0.05$, and 0.10 , respectively.

\subsection{Regression Results}

To test the hypotheses of our study, we conduct three panel regression approaches. First, we utilized the pooled ordinary least squares (OLS) to deal with independence of observations concern with each firm over time. The pooled OLS has been done employing the robust standard errors that clustered by firm and adjusted for heteroskedasticity. Second, we implement the test of Breusch and Pagan Lagrangian multiplier in order to select the most suitable estimator among pooled OLS and random effects. The result of test suggests to go for random effects estimator. Lastly, we utilize the Hausman test in order to select the appropriate estimator between the random effects and the fixed effects. The result of Hausman test shows that the fixed effects estimator is more effective. Therefore, hypotheses of this study are examined using both fixed effects and random effects regressions with controlling for time-invariant firm-specific effects. Since the fixed effects regression is the most suitable, the interpretations are according to the findings of the fixed effects regressions.

The results of regressing stock return on environmental disclosure score are outlined in Table 4. The results show that ENV disclosure score is significantly and negatively related with the stock return, signifying that a higher level of firm environmental disclosure decreases the stock return of Saudi listed firms. That is, the hypothesis H1 is rejected and the result is not in line with stakeholder theory and agency theory.

A plausible reason behind the negative result is that ENV practices can be value relevant for the investors and other stakeholders but they are not effectively integrated into the stock return. There is a lack of attention amongst the Saudi market authorities concerning the CSR disclosure as they may feel that the disclosure of CSR is not important for investors (Alotaibi and Hussainey 2016). It is worth noting that, the environmental disclosure is not mandatory in Saudi Arabia though there are increasingly great pressures on environmental issues. 
Table 4. The impact of environmental disclosures on stock return.

\begin{tabular}{|c|c|c|c|}
\hline Variables & Pooled OLS & Random-Effects & Fixed-Effects \\
\hline Intercept & $\begin{array}{c}0.705 * \\
(2.16)\end{array}$ & $\begin{array}{c}0.815^{* *} \\
(2.18)\end{array}$ & $\begin{array}{l}2.750 * \\
(2.15)\end{array}$ \\
\hline ENV & $\begin{array}{c}-0.025^{* *} \\
(-2.59)\end{array}$ & $\begin{array}{c}-0.029 \text { ** } \\
(-2.49)\end{array}$ & $\begin{array}{c}-0.151^{* * *} \\
(-3.70)\end{array}$ \\
\hline Size & $\begin{array}{l}0.218 \\
(1.49)\end{array}$ & $\begin{array}{l}0.023 \\
(1.65)\end{array}$ & $\begin{array}{l}0.030 * \\
(2.08)\end{array}$ \\
\hline ROA & $\begin{array}{l}0.040 * \\
(2.15)\end{array}$ & $\begin{array}{l}0.042 \text { * } \\
(2.00)\end{array}$ & $\begin{array}{l}0.046 \\
(1.20)\end{array}$ \\
\hline ASSETGROWTH & $\begin{array}{l}-0.755 \\
(-0.71) \\
\end{array}$ & $\begin{array}{l}-1.074 \\
(-1.01) \\
\end{array}$ & $\begin{array}{l}-1.657 \\
(-1.43) \\
\end{array}$ \\
\hline DEBT & $\begin{array}{c}-0.035 * * * \\
(-4.87)\end{array}$ & $\begin{array}{c}-0.036^{* * *} \\
(-4.12)\end{array}$ & $\begin{array}{l}-0.021 \\
(-0.51)\end{array}$ \\
\hline МТВ & $\begin{array}{l}0.169 \\
(1.90) \\
\end{array}$ & $\begin{array}{l}0.158 \\
(1.69) \\
\end{array}$ & $\begin{array}{l}-0.022 \\
(-0.18)\end{array}$ \\
\hline Year_FE & No & No & Yes \\
\hline Industry_FE & No & No & Yes \\
\hline Sample Size & 170 & 170 & 170 \\
\hline F-Statictic & $7.39^{* * *}$ & $37.79^{* * *}$ & $5.24^{* * *}$ \\
\hline Adjusted $\mathrm{R}^{2}$ & 0.193 & 0.389 & 0.115 \\
\hline $\begin{array}{c}\text { Breusch-Pagan LM test } \\
\text { Hausman Test }\end{array}$ & & $\begin{array}{l}0.58^{* *} \\
14.71^{* *}\end{array}$ & \\
\hline
\end{tabular}

Note: In this table, the results from regressing ENV (environmental disclosures) on stock return (R) are presented using pooled OLS, random effects and fixed effects, respectively. The utilized control variables are firm size (SIZE), firm profitability (ROA), growth rate of assets (ASSETGROWTH), firm debt (DEBT) and market to book ratio (MTB). ***,**, and * demonstrate the levels of significance at: $0.01,0.05$, and 0.10 , respectively.

The result may also be attributed to the economic argument of Mănescu (2011) that the returns of firms with better ESG will be reduced when the advantages of ESG practices and initiatives are less than its costs as well as partly informed investors overvalue benefits or undervalue costs. Further, it is argued by Barnea and Rubin (2010) that the ESG level of performance could be a cause of the agency costs since the management of firms are more inclined to support the investment in ESG at the expense of shareholders' interests with the purpose of increasing their reputational benefits. In the same vein, Kochhar (1996) claims that when there is low controlling on CSR, the agency conflict will be increased, which may result in impacting the stock price fluctuations as a consequence of the conflict between firm's management and shareholders.

Another reason behind the finding is the risk-factor argument. Mănescu (2011) claims that returns of firms with low level of ESG are greater mostly since they involve nonsustainability risk premium. In line with the raising of consciousness concerning nonsustainability risk and accessibility of information, it is assumed that, ESG factors can act as systematic risk. Consequently, the negative relationship between ENV disclosure score and stock returns can be attributable to reward paid for non-sustainability risk. That is, firms with greater ENV shows less risk and hence the stock returns will be lower.

Thus, whether the impact of ESG on stock return is explained by economic argument or risk-factor argument, the information on ESG practices should be accessible by investors, and there should be adequate investors who care. Mănescu (2011) argues that following economic and risk-factor arguments, the impact of ESG practices on stock returns may differ over time.

Our result is in line with Brammer et al. (2006) who point out that great environmental scores result in lower returns. They add that, investing in firms related with the lowest environmental score will result in $70 \%$ higher annualized returns, than firms with the 
highest environmental scores. Further, Belkaoui (1976) document that the influence of higher environmental disclosure on stock price is temporarily. The result of Halbritter and Dorfleitner (2015) indicate that there are no significant return differences for great or low ESG scores of firms. Tasnia et al. (2020) indicate that CSR is positively and significantly related to the volatility of stock price. They argue that investors do not have a preference for more focus on CSR owing to the added cost associated with this more focus. Finally, it can be reported that there is no definite evidence that better ESG firms gain greater returns.

Concerning the control variables, in the fixed effects regressions, only the SIZE is found to be significantly and positively related with stock return indicating that stocks of large firms are associated with higher return than other firms.

Table 5 represents the results of regressing the financial constraints (FC) on the association between environmental disclosure score (ENV) on stock return (R) using pooled OLS, random effects and fixed effects, respectively. The results in Table 5 indicate that FC has a negative and significant relationship with stock return, indicating that a financial constrained firms have lower stock return compared to their peers.

Table 5. The moderating impact of financial constraints on the association between environmental disclosures and stock return.

\begin{tabular}{|c|c|c|c|}
\hline Variables & Pooled OLS & Random-Effects & Fixed-Effects \\
\hline Intercept & $\begin{array}{l}1.213^{* *} \\
(3.25)\end{array}$ & $\begin{array}{c}1.450 * * \\
(3.33)\end{array}$ & $\begin{array}{l}3.956^{* *} \\
(3.10)\end{array}$ \\
\hline $\mathrm{FC}^{*} \mathrm{ENV}$ & $\begin{array}{l}0.027 \\
(1.28)\end{array}$ & $\begin{array}{l}0.036 \\
(1.58)\end{array}$ & $\begin{array}{l}0.066^{* *} \\
(2.35)\end{array}$ \\
\hline FC & $\begin{array}{l}-1.179 * \\
(-2.60)\end{array}$ & $\begin{array}{l}-1.445^{* *} \\
(-2.83)\end{array}$ & $\begin{array}{l}-2.503 * * \\
(-3.52)\end{array}$ \\
\hline ENV & $\begin{array}{l}-0.039 * * \\
(-3.31)\end{array}$ & $\begin{array}{l}-0.047 * * \\
(-3.36)\end{array}$ & $\begin{array}{l}-0.180 * * * \\
(-4.36)\end{array}$ \\
\hline Size & $\begin{array}{l}0.027 \\
(1.85)\end{array}$ & $\begin{array}{l}0.030 * * \\
(2.14)\end{array}$ & $\begin{array}{l}0.041^{* *} \\
(2.91)\end{array}$ \\
\hline ROA & $\begin{array}{l}0.030 \\
(1.56)\end{array}$ & $\begin{array}{l}0.032 \\
(1.47)\end{array}$ & $\begin{array}{l}0.039 \\
(1.06)\end{array}$ \\
\hline ASSETGROWTH & $\begin{array}{l}-0.496 \\
(-0.47)\end{array}$ & $\begin{array}{l}-0.805 \\
(-0.76)\end{array}$ & $\begin{array}{l}-1.148 \\
(-1.03)\end{array}$ \\
\hline DEBT & $\begin{array}{l}-0.028 * * \\
(-3.49)\end{array}$ & $\begin{array}{l}-0.028 * * \\
(-2.90)\end{array}$ & $\begin{array}{l}-0.020 \\
(-0.50)\end{array}$ \\
\hline MTB & $\begin{array}{l}0.108 \\
(1.19)\end{array}$ & $\begin{array}{l}0.096 \\
(1.00)\end{array}$ & $\begin{array}{l}-0.091 \\
(-0.74)\end{array}$ \\
\hline Year_FE & No & No & Yes \\
\hline Industry_FE & No & No & Yes \\
\hline Sample Size & 170 & 170 & 170 \\
\hline F-Statictic & $6.63^{* * *}$ & $46.50 * * *$ & $5.82 * * *$ \\
\hline Adjusted $\mathrm{R}^{2}$ & 0.220 & 0.360 & 0.281 \\
\hline $\begin{array}{c}\text { Breusch-Pagan LM test } \\
\text { Hausman Test }\end{array}$ & & $\begin{array}{l}22.85^{* *} \\
25.12^{* * *}\end{array}$ & \\
\hline
\end{tabular}

Note: This table illustrates the findings of regressing the moderating variable, financial constraints $\left(\mathrm{FC}^{*} \mathrm{ENV}\right)$ on the association between stock return (R) and firm environmental disclosures (ENV) and the control variables. The utilized control variables are firm size (SIZE), firm profitability (ROA), growth rate of assets (ASSETGROWTH), firm debt (DEBT) and market to book ratio (MTB). ***, ***, and ${ }^{*}$ demonstrate the levels of significance at: $0.01,0.05$, and 0.10 , respectively.

The estimated coefficient reported in Table 5 for the moderation variable $\mathrm{ENV}^{*} \mathrm{FC}$ is positive and statistically significant, indicating that the negative effect of environmental disclosures on stock return is aggravated by the presence of financial constraints. Thus, we do not find support for our second hypothesis $\mathrm{H} 2$ that suggests a negative effect of financial constraints on the association between environmental disclosures and stock return. If the financial constraints and its related intensified risk are recognized by investors, it 
is more likely investors will ask for a greater risk premium (He and Ren 2018). That is, they will require greater return to reward them for the greater risk they accept. To this end, with a high financial constraint, the ability of firms to invest in environmental activities will be less. In such case, the investors will be compensated by more stock return for the environmental and financial constraints risk.

\subsection{Additional Analysis}

In this section, we first replace our key independent variable (ENV) by the comprehensive and aggregated score of ESG. Following the study of Khan (2019), we checked the whole impact of environmental, social, and governance on stock return. Table 6 documents the results of regressing stock return on ESG. We find that higher level of firm ESG disclosures results in lower stock return. These results are opposite to the finding of Khan (2019) that uses an international sample.

Further, we test the impact of individual factors of ESG on the stock return. Specifically, we examine the effect of social score and governance score disclosure on stock return. The results show that, SOC is negatively and significantly related with stock return, indicating that social disclosures lower the stock performance which is opposite to the finding of Haniffa and Cooke (2005) and Karagiorgos (2010). Finally, the positive and significant result of GOV and stock return, reveals that governance disclosures lead to increasing the stock return.

Table 6. The impact of environmental, social, and corporate governance (ESG), social (SOC) and governance (GOV) disclosures on stock return.

\begin{tabular}{|c|c|c|c|}
\hline Variables & ESG & SOC & GOV \\
\hline Intercept & $\begin{array}{l}3.289^{*} \\
(2.78)\end{array}$ & $\begin{array}{l}3.616^{*} \\
(2.38)\end{array}$ & $\begin{array}{c}-2.504^{* * *} \\
(-4.55)\end{array}$ \\
\hline ESG & $\begin{array}{c}-0.028^{* *} \\
(-2.09)\end{array}$ & & \\
\hline SOC & & $\begin{array}{c}-0.033^{* *} \\
(-2.32)\end{array}$ & \\
\hline GOV & & & $\begin{array}{c}0.037^{* * *} \\
(3.94)\end{array}$ \\
\hline Size & $\begin{array}{c}0.032 \text { ** } \\
(2.31)\end{array}$ & $\begin{array}{c}0.047^{* * *} \\
(3.41)\end{array}$ & $\begin{array}{c}0.143^{* *} \\
(2.44)\end{array}$ \\
\hline ROA & $\begin{array}{l}-0.062 * \\
(-1.94)\end{array}$ & $\begin{array}{l}-0.061 \\
(-1.37)\end{array}$ & $\begin{array}{c}0.053^{* *} \\
(3.26)\end{array}$ \\
\hline ASSETGROWTH & $\begin{array}{l}0.045 \\
(0.03)\end{array}$ & $\begin{array}{l}-0.784 \\
(-0.42)\end{array}$ & $\begin{array}{l}-0.531 \\
(-0.48)\end{array}$ \\
\hline DEBT & $\begin{array}{c}-0.044^{* * *} \\
(-3.26)\end{array}$ & $\begin{array}{l}-0.043 * \\
(-2.36)\end{array}$ & $\begin{array}{c}-0.037^{* * *} \\
(-4.89)\end{array}$ \\
\hline МТВ & $\begin{array}{l}0.006 \\
(0.04)\end{array}$ & $\begin{array}{l}-0.019 \\
(-0.12)\end{array}$ & $\begin{array}{c}0.237^{* * *} \\
(3.03)\end{array}$ \\
\hline Year_FE & Yes & Yes & Yes \\
\hline Industry_FE & Yes & Yes & Yes \\
\hline Sample Size & 170 & 128 & 139 \\
\hline F-Statictic & $4.43 * * *$ & $8.07^{* * *}$ & $16.04^{* * *}$ \\
\hline Adjusted $\mathrm{R}^{2}$ & 0.254 & 0.309 & 0.358 \\
\hline
\end{tabular}

Note: The findings of regressing stock return (R) on ESG, SOC, GOV, and the control variables are illustrated in this table. The utilized control variables are firm size (SIZE), firm profitability (ROA), growth rate of assets (ASSETGROWTH), firm debt (DEBT) and market to book ratio (MTB). ***, **, and * demonstrate the levels of significance at: $0.01,0.05$, and 0.10 , respectively.

\subsection{Robustness Checks}

Our key models (1) and (2) are regressed using pooled OLS, random effects and fixed effects regressions with modifying all standard errors for firm-level clustering. Nonetheless, the association between environmental disclosures and stock return might include a possible endogeneity concern. As with similar ESG previous studies, the possible bias of omitted variables could deteriorate the explanation of the underlying association between environmental sustainability disclosure and stock return. In our models, we include a wide 
set of control variables (firms size, profitability, growth of firm assets, firm debt, market to book ratio, industry dummies, and year dummies) to certify that our reported findings are not determined by omitted variables. However, the impact of environmental disclosure on stock return might be driven by some omitted variables that are associated with both environmental disclosure and stock return.

In addition, a reverse causality might be existing (Ianniello and Galloppo 2020). Consequently, firms with higher environmental disclosures significantly decrease stock return but it is also likely that firms with high stock return are less likely to voluntarily disclose environmental information. In such case, the pooled OLS, random effects and fixed effects possibly will not be suitable.

According to the above reasoning, to alleviate the issues concerning endogeneity, reverse causality, and potential bias from omitted variables, we follow Arellano and Bond (1991) and include a lagged dependent variable ( $\mathrm{R}$ ) in both models (1) and (2). Additionally, we follow Zhou et al. (2020), Blundell and Bond (1998), and Arellano and Bover (1995) by employing dynamic generalized method of moments (GMM) estimator.

Table 7 displays the robustness check of the regression findings using dynamic panel GMM approach. The models (1) and (2) incorporates the dynamic direct relation (ENV and $\mathrm{R})$ and moderation relationship $\left(\mathrm{ENV}^{*} \mathrm{FC}\right.$ and $\left.\mathrm{R}\right)$, respectively. As reported in Table 7, we continue to find similar results after taking into account for endogeneity based on the dynamic GMM estimator, indicating that the conclusions of this study are reliable. That is, the environmental discourse is significantly and negatively related with stock return and this relationship is positively moderated by the financial constraints.

Table 7. Addressing endogeneity: generalized method of moments (GMM) approach.

\begin{tabular}{|c|c|c|}
\hline \multirow{2}{*}{ Variables } & \multicolumn{2}{|c|}{ GMM } \\
\hline & (1) & (2) \\
\hline Intercept & $\begin{array}{c}-4.993^{* * *} \\
(-4.84)\end{array}$ & $\begin{array}{c}-3.886^{* *} \\
(-3.45)\end{array}$ \\
\hline Lag R & $\begin{array}{c}0.327^{* * *} \\
(8.05)\end{array}$ & $\begin{array}{c}0.2169^{* * *} \\
(4.47)\end{array}$ \\
\hline ENV & $\begin{array}{c}-0.047^{* *} \\
(2.24)\end{array}$ & $\begin{array}{c}-0.036^{* *} \\
(-2.53)\end{array}$ \\
\hline $\mathrm{FC} * \mathrm{ENV}$ & & $\begin{array}{c}0.047^{* *} \\
(2.01)\end{array}$ \\
\hline FC & & $\begin{array}{l}-1.802 \text { ** } \\
(-2.61)\end{array}$ \\
\hline Size & $\begin{array}{c}0.424^{* * *} \\
(6.11)\end{array}$ & $\begin{array}{c}0.362^{* * *} \\
(4.03)\end{array}$ \\
\hline ROA & $\begin{array}{l}0.058^{*} \\
(2.51)\end{array}$ & $\begin{array}{c}0.072 \text { ** } \\
(3.09)\end{array}$ \\
\hline ASSETGROWTH & $\begin{array}{l}1.368 \\
(0.88)\end{array}$ & $\begin{array}{l}-0.549 \\
(-0.55)\end{array}$ \\
\hline DEBT & $\begin{array}{l}-0.025 \\
(-1.42)\end{array}$ & $\begin{array}{l}-0.009 \\
(-0.45)\end{array}$ \\
\hline MTB & $\begin{array}{l}0.163 * \\
(2.41)\end{array}$ & $\begin{array}{l}0.119 \\
(1.63)\end{array}$ \\
\hline Year_FE & Yes & Yes \\
\hline Industry_FE & Yes & Yes \\
\hline Sample Size & 130 & 130 \\
\hline F statistic & $771.73^{* * *}$ & $777.56^{* * *}$ \\
\hline $\mathrm{AR}(1)$ test ( $p$-value) & -1.89 & -1.80 \\
\hline $\operatorname{AR}(2)$ test ( $p$-value) & 0.61 & 0.41 \\
\hline Hansen-J test of over-identification ( $p$-value) & 23.04 & 24.29 \\
\hline
\end{tabular}

Note: The results from regressing stock return (R) on ENV besides financial constraints (FC) on the connotation between ENV and R and other control variables are presented in this Table employing GMM approach. The utilized control variables are firm size (SIZE), firm profitability (ROA), growth rate of assets (ASSETGROWTH), firm debt (DEBT) and Market to book ratio (MTB). ${ }^{* * *},{ }^{* *}$, and * demonstrate the levels of significance at: $0.01,0.05$, and 0.10 , respectively. 


\section{Conclusions}

The present study explores and examines an interesting issue concerning the impact of environmental sustainability disclosure on stock return of Saudi listed firms. Further it examines the role of financial constraints in moderating environmental sustainability disclosure-stock return relationship. The reported results indicate that higher level of environmental disclosure leads to lower stock return. The result indicates that investors do not recognize the differences in environmental disclosure scores as a sign of a lower/higher risk. That is, investors are not willing to pay a premium price for the disclosed environmental activities and performance.

In addition, the results propose that the negative influence of environmental disclosure on stock return is more pronounced in firms with more financial constraints. Indeed, the capability of financially constrained firms to allocate more financial resources for enhancing its environmental initiatives will be less. Investors will be asking for higher reward of return for the risk associated with environmental performance and financial constraints.

This study contributes to literature by adding and enriching existing understanding on the issues of stock return, environmental disclosure, and financial constraints in Saudi Arabia as an emerging market. From a practical perspective, we suggest that management of firms should reflect environmental sustainability practices as a way to enhance the reputation of firm and attract the investors. That is, for firms to get benefits from environmental performance, the policies and strategies of environmental sustainability should be essential for firm strategies. Thus, environmental practices should be responsible and not only a method to reduce the damage of some environmental problems. For investors, environmental sustainability practices are important as it will offer them new evidence that practices and initiatives of environmental sustainability are value relevant or that the risk of low or poor environmental sustainability might be present.

Like other studies, some limitations are noted in this study in order to accurately interpret the findings. These limitations should direct the opportunities of future research. First, the study sample excluded all Saudi financial and real estate listed firms, as a result of their dissimilar regulations. Thus, the study results may not be suitable to be generalized to these firms. Hence, future studies could investigate the issue of the study in financial and real estate listed firms. Further, excluding these firms resulted in small sample size for our study. Therefore, it is of interest for future studies to investigate larger sample to help in making more generalized conclusions. Second, the study focuses on Saudi listed firms which makes the generalization of results limited for capital markets of other countries that vary in size, regulations and economics structures. Future studies could be done in other countries. Future studies may also examine the moderating role of some internal corporate governance mechanisms like board independence and ownership structure on the association of environmental disclosure and stock return. Finally, our study used many control variables to mitigate the issue that the results are determined by omitted variables. However, future studies may address many other variables that could have an effect on stock return and environmental disclosure.

Author Contributions: All authors contributed equally to the paper in terms of research design, collecting and analyzing data as well as in writing the paper. All authors have read and agreed to the published version of the manuscript.

Funding: This research was funded by the Deputyship for Research \& Innovation, Ministry of Education in Saudi Arabia.

Acknowledgments: The authors extend their appreciation to the Deputyship for Research \& Innovation, Ministry of Education in Saudi Arabia for funding this research work through the project number IFT20039.

Conflicts of Interest: The authors declare no conflict of interest. 


\section{References}

Alhazmi, Anas. 2017. Exploring the Factors and Effects of Corporate Social Responsibility Disclosure in Saudi Arabia. Ph.D. thesis, Nottingham Trent University, Nottingham, UK.

Ali, Abbas, and Abdulrahman Al-Aali. 2012. Corporate Social Responsibility in Saudi Arabia. Middle East Policy 19: 40-53. [CrossRef]

Almeida, Heitor, Murillo Campello, and Michael Weisbach. 2004. The cash flow sensitivity of cash. The Journal of Finance 59: 1777-804. [CrossRef]

Alotaibi, Khaleed, and Khaled Hussainey. 2016. Determinants of CSR disclosure quantity and quality: Evidence from non-financial listed firms in Saudi Arabia. International Journal of Disclosure and Governance 13: 364-93. [CrossRef]

Ammer, Mohammed Abdullah, and Nurwati A. Ahmad-Zaluki. 2017. The effect of disclosure regulation on the bias and accuracy of management earnings forecasts in Malaysian IPO prospectuses. Journal of Financial Reporting and Accounting 15: 59-77. [CrossRef]

Andreea, Semenescu, and Curmei Valeriu. 2015. Using CSR to mitigate information asymmetry in the banking sector. Management $\mathcal{E}$ Marketing 10: 316-29.

Arellano, Manuel, and Stephen Bond. 1991. Some tests of specification for panel data: Monte Carlo evidence and an application to employment equations. Review of Economic Studies 58: 277-97. [CrossRef]

Arellano, Manue, and Olympia Bover. 1995. Another look at the instrumental variable estimation of error-components models. Journal of Econometrics 68: 29-51. [CrossRef]

Astakhov, Anton, Tomas Havranek, and Jiri Novak. 2019. Firm Size and Stock Returns: A Quantitative Survey. Journal of Economic Surveys 33: 1463-92. [CrossRef]

Barnea, Amir, and Amir Rubin. 2010. Corporate social responsibility as a conflict between shareholders. Journal of Business Ethics Volume 97: 71-86. [CrossRef]

Belkaoui, Ahmed. 1976. The impact of the disclosure of the environmental effects of organizational behavior on the market. Financial Management 5: 26-31. [CrossRef]

Bénabou, Roland, and Jean Tirole. 2010. Individual and Corporate Social Responsibility. Economica 77: 1-19. [CrossRef]

Bhattacharyya, Asit, and Lorne Cummings. 2015. Measuring corporate environmental performance-Stakeholder engagement evaluation. Business Strategy and the Environment 24: 309-25. [CrossRef]

Blundell, Richard, and Stephen Bond. 1998. Initial conditions and moment restrictions in dynamic panel data models. Journal of Econometrics 87: 115-43. [CrossRef]

Bolton, Patrick, and Marcin Kacperczyk. 2020. Do Investors Care about Carbon Risk? NBER Working Papers Series 26968. Available online: https: / / www.nber.org/papers/w26968 (accessed on 18 October 2020).

Brammer, Stephen, Chris Brooks, and Stephen Pavelin. 2006. Corporate Social Performance and Stock Returns UK Evidence from Disaggregate Measures. Financial Management 35: 97-116. [CrossRef]

Campello, Murillo, and Long Chen. 2010. Are financial constraints priced? Evidence from firm fundamentals and stock returns. Journal of Money, Credit and Banking 42: 1185-98. [CrossRef]

Campello, Murillo, John Graham, and Campbell Harvey. 2010. The real effects of financial constraints: Evidence from a financial crisis. Journal of Financial Economics 97: 470-87. [CrossRef]

Capelle-Blancard, Gunther, and Aure'lien Petit. 2019. Every little helps? ESG news and stock market reaction. Journal of Business Ethics 157: 543-65. [CrossRef]

Chen, Sheng-Syan, and Yanzhi Wang. 2012. Finance constraints and stock repurchases. Journal of Financial Economics 105: 311-31. [CrossRef]

Cheng, Beiting, Ioannis Ioannou, and George Serafeim. 2014. Corporate social responsibility and access to finance. Strategic Management Journal 35: 1-23. [CrossRef]

Cho, Charles, and Dennis Patten. 2007. The role of environmental disclosures as tools of legitimacy: A research note. Accounting, Organizations and Society 32: 639-47. [CrossRef]

Cooper, Michael, Huseyin Gulen, and Michael Schill. 2008. Asset growth and the cross-section of stock returns. Journal of Finance 63: 1609-52. [CrossRef]

Cowton, Christopher, and Paul Thompson. 2000. Do codes make a difference? The case of bank lending and the environment. Journal of Business Ethics 24: 165-78. [CrossRef]

Dbouk, Wassim, Dawei Jin, Haizhi Wang, and Jianrong Wang. 2018. Corporate Social Responsibility and Rule 144A Debt Offerings: Empirical Evidence. International Journal of Financial Studies 6: 94. [CrossRef]

Dechow, Patricia, Richard Sloan, and Amy Sweeney. 1996. Causes and consequences of earnings manipulation: An analysis of firms subject to enforcement actions by the SEC. Contemporary Accounting Research 13: 1-36. [CrossRef]

Dusuki, Asyraf, and Nurdianawati Abdullah. 2007. Maqasid Al-Shari'ah, Maslahah and Corporate Social Responsibility. The American Journal of Islamic Social Sciences 24: 25-45. [CrossRef]

Eccles, Robert, Ioannis Ioannou, and George Serafeim. 2014. The impact of corporate sustainability on organizational processes and performance. Management Science 60: 2835-57. [CrossRef]

Eljayash, Kamal, Kieran James, and Eric Kong. 2012. The quantity and quality of environmental disclosure in annual reports of national oil and gas companies in the Middle East and North Africa. International Journal of Economics and Finance 4: 201-17. [CrossRef]

Ender, Manuela, and Finn Brinckmann. 2019. Impact of CSR-Relevant News on Stock Prices of Companies Listed in the Austrian Traded Index (ATX). International Journal of Financial Studies 7: 36. [CrossRef] 
Fatemi, Ali, Martin Glaum, and Stefanie Kaiser. 2018. ESG performance and firm value: The moderating role of disclosure. Global Finance Journal 38: 45-64. [CrossRef]

Fazzari, Steven, Glenn Hubbard, Bruce Petersen, Alan Blinder, and James Poterba. 1988. Financing constraints and corporate investment. Brookings Papers on Economic Activity 2: 141-206. [CrossRef]

Fowlie, Meredith, Michael Greenstone, and Catherine Wolfram. 2015. Do Energy Efficiency Investments Deliver? Evidence from the Weatherization Assistance Program. NBER Working Paper, No. 21331. Available online: https://www.nber.org/papers/w21331 (accessed on 18 October 2020).

Friedman, Milton. 1970. The Social Responsibility of Business is to Increase its Profits. New York Times Magazine. Available online: http:/ / umich.edu/ \{\}thecore/doc/Friedman.pdf (accessed on 18 October 2020).

Gerged, Ali, Christopher Cowton, and Eshani Beddewela. 2018. Towards sustainable development in the Arab Middle East and North Africa region: A longitudinal analysis of environmental disclosure in corporate annual reports. Business Strategy and the Environment 27: 572-87. [CrossRef]

Giese, Guido, and Zoltan Nagy. 2018. How Markets price Esg? Have Changes in ESG Scores Affected Stock Prices? MSCI, 1-25. Available online: https://www.msci.com/documents/10199/f3f252a7-0dbd-035b-e67c-964a87fbcd03(accessed on 20 October 2020).

Godfrey, Paul, Craig Merrill, and Jared Hansen. 2009. The relationship between corporate social responsibility and shareholder value: An empirical test of the risk management hypothesis. Strategic Management Journal 30: 425-45. [CrossRef]

Götz, Martin. 2018. Financial Constraints and Corporate Environmental Responsibility. SAFE Working Paper No. 241. Frankfurt: Goethe University.

Greenstone, Michael, John List, and Chad Syverson. 2012. The Effects of Environmental Regulation on the Competitiveness of U.S. Manufacturing. NBER Working Paper, No. 18392. Available online: https://www.nber.org/papers/w18392 (accessed on 20 October 2020).

Gregory-Smith, Diana, Danae Manika, and Pelin Demirel. 2017. Green intentions under the blue flag: Exploring differences in EU consumers' willingness to pay more for environmentally-friendly products. Business Ethics: A European Review 26: 205-22. [CrossRef]

Grubor, Aleksandar, Nemanja Berber, Marko Aleksić, and Radmila Bjekić. 2020. The influence of corporate social responsibility on organizational performance: A research in AP Vojvodina. The Annals of the Faculty of Economics in Subotica 56: 3-13. [CrossRef]

Halbritter, Gerhard, and Gregor Dorfleitner. 2015. The wages of social responsibility—Where are they? A critical review of ESG investing. Review of Financial Economics 26: 25-35. [CrossRef]

Haniffa, Roszaini, and Terence Cooke. 2005. The Impact of Culture and Governance on Corporate Social Reporting. Journal of Accounting and Public Policy 24: 391-430. [CrossRef]

He, Guanming, and Helen Ren. 2018. Financial Constraints and Futures Stock Price Crash Risk; Working Paper. Durham: Durham University. Available online: http://www.fmaconferences.org/Boston/Financial_Constraints_and_Future_Stock_Price_Crash_ Risk.pdf (accessed on 20 October 2020).

Healy, Paul, Amy Hutton, and Krishna Palepu. 1999. Stock performance and intermediation changes surrounding sustained increases in disclosure. Contemporary Accounting Research 16: 485-520. [CrossRef]

Helfaya, Akrum, and Mark Whittington. 2019. Does designing environmental sustainability disclosure quality measures make a difference? Business Strategy and the Environment 28: 525-41. [CrossRef]

Hong, Harrison, Jeffrey Kubik, and Jose Scheinkman. 2012. Financial Constraints on Corporate Goodness. NBER Working Paper Series 18476. Available online: https://www.nber.org/system/files/working_papers/w18476/w18476.pdf (accessed on 18 October 2020).

Hussainey, Khaled, and Aly Salama. 2010. The importance of corporate environmental reputation to investors. Journal of Applied Accounting Research 11: 229-41. [CrossRef]

Ianniello, Giuseppe, and Giuseppe Galloppo. 2020. Voluntary Disclosure of Stock Performance in Management Reports: Italian Evidence. International Journal of Business and Social Science 11: 31-44. [CrossRef]

Indriastuti, Maya, and Naila Najihah. 2020. Stock Return Movement in Indonesia Mining Companies. Advances in Economics, Business and Management Research 115: 54-57.

Jacobs, Brian, Vinod Singhal, and Ravi Subramanian. 2010. An empirical investigation of environmental performance and the market value of the firm. Journal of Operations Management 28: 430-41. [CrossRef]

Jizi, Mohammad, Rabih Nehme, and Aly Salama. 2016. Do social responsibility disclosures show improvements on stock price? The Journal of Developing Areas 50: 77-95. [CrossRef]

Karagiorgos, Theofanis. 2010. Corporate social responsibility and financial performance: An empirical analysis on Greek companies. European Research Studies Journal 13: 85-108. [CrossRef]

Karamanou, Irene, and Nikos Vafeas. 2005. The association between corporate boards, audit committees, and management earnings forecasts: An empirical analysis. Journal of Accounting Research 43: 453-86. [CrossRef]

Khan, Mozaffar. 2019. Corporate governance, ESG, and stock returns around the world. Financial Analysts Journal 75: 103-23. [CrossRef]

Klassen, Robert, and Curtis McLaughlin. 1996. The impact of environmental management on firm performance. Management Science 42: 1199-214. [CrossRef] 
Kochhar, Rahul. 1996. Explaining firm capital structure: The role of agency theory vs transaction cost economics. Strategic Management Journal 17: 713-28. [CrossRef]

Kurt, Ahmet. 2018. How do financial constraints related to financial reporting quality? Evidence from seasoned equity offerings. European Accounting Review 27: 527-57. [CrossRef]

La Torre, Mario, Fabiomassimo Mango, Arturo Cafaro, and Sabrina Leo. 2020. Does the ESG Index Affect Stock Return? Evidence from the Eurostoxx50. Sustainability 12: 6387. [CrossRef]

Lambert, Richard, Christian Leuz, and Robert Verrecchia. 2007. Accounting information, disclosure, and the cost of capital. Journal of Accounting and Research 45: 385-420. [CrossRef]

Lamont, Owen, Christopher Polk, and Jesús Saaá-Requejo. 2001. Financial constraints and stock returns. Review of Financial Studies 14: 529-54. [CrossRef]

Li, Xiafei, and Di Luo. 2019. Financial constraints, stock liquidity, and stock returns. Journal of International Financial Markets Institutions and Money 63: 101139. [CrossRef]

Limkriangkrai, Manapon, Szekee Koh, and Robert Durand. 2017. Environmental, social, and governance (ESG) profiles, stock returns, and financial policy: Australian evidence. International Review of Finance 17: 461-71. [CrossRef]

Livdan, Dmitry, Horacio Sapriza, and Lu Zhang. 2009. Financially constrained stock returns. Journal of Finance 64: 1827-62. [CrossRef]

Llena, Fernando, Jose Moneva, and Blanca Hernandez. 2007. Environmental disclosures and compulsory accounting standards: The case of Spanish annual reports. Business Strategy and the Environment 16: 50-63. [CrossRef]

Mănescu, Cristiana. 2011. Stock returns in relation to environmental, social, and governance performance: Mispricing or compensation for risk? Sustainable Development 19: 95-118. [CrossRef]

Manita, Riadh, Maria Bruna, Rey Dang, and L'Hocine Houanti. 2018. Board gender diversity and ESG disclosure: Evidence from the USA. Journal of Applied Accounting Research 19: 206-24. [CrossRef]

Miralles-Quiros, Maria, Jose Miralles-Quiros, and Irene Arraiano. 2017. Sustainable development, sustainability leadership and firm valuation: Differences across Europe. Business Strategy and the Environment 26: 1014-28. [CrossRef]

Nizam, Esma, Adam Ng, Ginanjar Dewandaru, Ruslan Nagayev, and Malik Nkoba. 2019. The impact of social and environmental sustainability on financial performance: A global analysis of the banking sector. Journal of Multinational Financial Management 49 : 35-53. [CrossRef]

Nollet, Joscha, George Filis, and Evangelos Mitrokostas. 2016. Corporate social responsibility and financial performance: A non-linear and disaggregated approach. Economic Modelling 52: 400-7. [CrossRef]

Pava, Moses, and Joshua Krausz. 1996. The association between corporate social-responsibility and financial performance: The paradox of social cost. Journal of Business Ethics 15: 321-57. [CrossRef]

Pizzutilo, Fabio, Massimo Mariani, Alessandra Caragnano, and Marianna Zito. 2020. Dealing with Carbon Risk and the Cost of Debt: Evidence from the European Market. International Journal of Financial Studies 8: 61. [CrossRef]

Plumlee, Marlene, Darrell Brown, Rachel Hayes, and Scott Marshall. 2010. Voluntary environmental disclosure and firm value: Further evidence. Journal of Accounting and Public Policy 34: 336-61. [CrossRef]

Porter, Michael. 1991. America's green strategy. Scientific American 264: 168. [CrossRef]

Rubino, Franco, and Francesco Napoli. 2020. What Impact Does Corporate Governance Have on Corporate Environmental Performances? An Empirical Study of Italian Listed Firms. Sustainability 12: 5742. [CrossRef]

Sahut, Jean-Michel, and Hélène Pasquini-Descomps. 2015. ESG impact on market performance of firms: International evidence. Management International 19: 40-63. [CrossRef]

Stekelenburg, Akim, Georgios Georgakopoulos, Virginia Sotiropoulou, and Konstantinos Vasileiou. 2015. The relation between sustainability performance and stock market returns: An empirical analysis of the Dow Jones Sustainability Index Europe. International Journal of Economics and Finance 7: 74-88. [CrossRef]

Sun, Nan, Aly Salama, Khaled Hussainey, and Murya Habbash. 2010. Corporate environmental disclosure, corporate governance and earnings management. Managerial Auditing Journal 25: 679-700. [CrossRef]

Tasnia, Mashiyat, Syed AlHabshi, and Romzie Rosman. 2020. The impact of corporate social responsibility on stock price volatility of the US banks: A moderating role of tax. Journal of Financial Reporting and Accounting. [CrossRef]

Tirole, Jean. 2006. The Theory of Corporate Finance. Princeton: Princeton University Press.

Walker, Reed. 2011. Environmental regulation and labor reallocation: Evidence from the clean air act. American Economic Review 101: 442-47. [CrossRef]

Xiao, Han, and KeMin Wang. 2020. Does environmental labeling exacerbate heavily polluting firms' financial constraints? Evidence from China. China Journal of Accounting Research 13: 147-74. [CrossRef]

Yao, Sheng, Yuan Hong, and Chen-Miao Lin. 2019. Environmental Information Disclosure and Financial Constraint. Asia-Pacific Journal of Financial Studies 48: 666-89. [CrossRef]

Zhang, Haifeng, Zhuo Zhang, and Ekaterina Steklova. 2020. Do Companies Need Financial Flexibility for Sustainable Development? Sustainability 12: 1811. [CrossRef]

Zhou, Xiaoyan, Ben Caldecott, Elizabeth Harnett, and Kim Schumacher. 2020. The Effect of Firm-Level ESG Practices on Macroeconomic Performance. Working Paper No. 20-03. Oxford: University of Oxford. 